\title{
Effect of nano- and crystalline metal oxides on growth, gene- and cytotoxicity of plants in vitro and ex vitro
}

\author{
S. I. Kolesnikov ${ }^{1}$, T. V. Varduny ${ }^{2}$, V. S. Lysenko ${ }^{2}$, O. A. Kapralova², V. A. Chokheli², \\ M. M. Sereda ${ }^{2}$, P. A. Dmitriev ${ }^{2}$, V. M. Varduny ${ }^{2}$ \\ ${ }^{1}$ Academy of Biology and Biotechnology of the Southern Federal University, Prospekt Stachki 7, Rostov-on-Don, \\ 344041, Russian Federation.E-mail: kolesnikov@sfedu.ru \\ ${ }^{2}$ Botanical garden of the Southern Federal University, Botanicheskiy spusk, 7, Rostov-on-Don, 344041, Russian Federation. \\ E-mail:pressreal@gmail.com
}

Keywords: chromosomal aberrations, nanoparticles, root mitotic index, tissue culture.

Summary. Results of the research on the phytotoxic, cytotoxic and genotoxic effects revealed in common wheat (Triticum aestivum L.) plants germinated from seeds treated with nanooxide iron $\left(\mathrm{Fe}_{2} \mathrm{O}_{3} \mathrm{NP}\right)$ and crystalline iron oxide $\left(\mathrm{Fe}_{2} \mathrm{O}_{3} \mathrm{cr}\right.$.) are described. Stimulating effects of the majority of their studied concentrations on cell division and tissue growth were demonstrated. Effects of $\mathrm{Fe}_{2} \mathrm{O}_{3} \mathrm{NP}$ and $\mathrm{Fe}_{2} \mathrm{O}_{3}$ cr. also have been studied on growth and development of the tomato (Lycopersicon esculentum L.) tissues cultivated in vitro. It has been shown that $\mathrm{Fe}_{2} \mathrm{O}_{3} \mathrm{NP}$ and $\mathrm{Fe}_{2} \mathrm{O}_{3}$ cr. induced both inhibitory and stimulating effects depending on the concentrations applied.

\section{Влияние нанооксидов и кристаллических оксидов железа на рост, генотоксичность и цитотоксичность растений in vitro и ex vitro}

\author{
С. И. Колесников ${ }^{1}$, Т. В. Вардуни ${ }^{2}$ В. С. Лысенко ${ }^{2}$ О. А. Капралова ${ }^{2}$, В. А. Чохели ${ }^{2}$ \\ М. М. Середа², П. А. Дмитриев², В. М. Вардуни ${ }^{2}$ \\ ${ }^{1}$ Академия биологии и биотехнологии Южного федерального университета, пр. Стачки, 194, \\ 2. Ростов-на-Дону, 344041, Россия \\ ${ }^{2}$ Ботанический сад Южного федерального университета, пер. Ботанический спуск, 7 , \\ г. Ростов-на-Дону, 344041, Россия
}

Ключевые слова: корневой митотический индекс, культура тканей, наночастицы, хромосомные аберрации.

Аннотация. Исследована цитотоксичность, фитотоксичность и генотоксичность наночастиц $\left(\mathrm{Fe}_{2} \mathrm{O}_{3} \mathrm{NP}\right)$ и кристаллических препаратов оксида железа $\left(\mathrm{Fe}_{2} \mathrm{O}_{3} \mathrm{cr}\right.$.), выявляемая в экспериментах с растениями мягкой пшеницы (Triticum aestivum L.) после обработки этими препаратами ее семян. Показано стимулирующее влияние большинства концентраций суспензий оксидов железа на деление клеток и рост тканей. Также изучено влияние $\mathrm{Fe}_{2} \mathrm{O}_{3} \mathrm{NP}$ и $\mathrm{Fe}_{2} \mathrm{O}_{3}$ cr. на рост и развитие растений томата (Lycopersicon esculentum L.) in vitro культуре тканей. Показано, что $\mathrm{Fe}_{2} \mathrm{O}_{3} \mathrm{NP}$ и $\mathrm{Fe}_{2} \mathrm{O}_{3}$ cr. оказывали стимулирующие и ингибирующие воздействия в зависимости от концентрации. 


\section{Introduction}

In recent years biological effects induced in plants by nanoparticles (NP) are of a wide interest due to the industrial technology development and the nanoparticle emission incoming into the environment together with the industrial waste, production and materials (Siddiqui et al., 2015). Application of nanoparticles is quite promising in plant biotechnology, where their antibacterial and stimulating effects are confirmed by several researchers (reviewed by Kim et al., 2015).

Considerable expectations are being placed on the preparations developed on the basis of nanotechnology and designated for the agriculture and crop production, especially for plant growth stimulating (Godimchuk, Ikhalainen, 2013). Application of NP-based preparations may also contribute in the increasing of plant resistance to adverse environmental conditions. A number of chemical elements including iron, cobalt, copper, manganese etc. is known to stimulate plant growth and development, but it would be a wrong idea to assert this in every separate case (Vinogradov, 2010).

Nanoparticles have an ability to penetrate unhindered into seed cells actively influencing enzyme system thus increasing germination (Nazarova et al., 2012; Kolesnikov et al., 2016). Studies on the interaction of nanoparticles with plants have revealed both positive and negative effects related with the germination energy and root length (Lei et al., 2005; He et al., 2011) as well as with the influence inhibiting these processes (Barrena et al., 2009; Seeger et al., 2009; Ghodak et al., 2011).

Iron nanooxide is widely used for the magnetic media manufacturing and it is also comprised in the compositions of various preparations for the agriculture and crop production. Nanopowder of iron oxide $\mathrm{Fe}_{2} \mathrm{O}_{3}$ is applied as an effective adsorbent for heavy metals, for example, chromium from different environment and used as a contrast MRI-agent in clinics. Besides, it is applied in the producing pig-iron by the blast-furnace method, producing of ammonia, ceramics, mineral paints, glass and steel, in the food industry and for the production of modern building materials.

Results of the study on the rice plant development have revealed that growth rate of rice roots was significantly increased under the influence of 500, 1000 and $2000 \mathrm{mg} \mathrm{L}^{-1} \mathrm{Fe}_{2} \mathrm{O}_{3} \mathrm{NP}$ suspensions (Alidoust, Isoda, 2013).

Treatment of spring rapeseeds with Fe-NP in concentration $0.03 \mathrm{~kg} \mathrm{ha}^{-1}$ led to the increase of germination by 2-3\%. Application of NP positively influenced the content of water-soluble polysaccharides in the aboveground parts of plants (Churilov et al., 2010).

Stimulating effect of iron nanopowder was shown in the studies on accumulation of the ascorbic acid and carotene in Potentilla anserina and Polygonum aviculare plants. In addition, treatment of seeds of these plants with Fe NP increased their germination and yield by $25-32 \%$. Ascorbic acid content in the pants was increased by $24-37 \%$, carotene - by $23-$ $50 \%$, carbohydrates - by $23-50 \%$ depending on the plant species and longevity of vegetation period. Positive effects of Fe NP treatment were observed in sunflower, corn, spring wheat: field germination was increased by $8,12.6$ and $10.5 \%$ respectively; leaf blade square and photosynthesis intensity were increased by 15-25\% (Churilov et al., 2010).

In consequence, there was a considerable increase of the yield of these plants (Mahmoudi et al., 2012). Nanoparticles contained in the cultivation media in the concentration range from 26 to 6.25 nmoles induced growth stimulation of wheat (Triticum aestivum L.) seedlings (Deryabina, 2015).

Cytotoxic effects of iron oxide NPs are not studied enough, but it is known that they are not citotoxic for human in concentrations below 100 mg L ${ }^{-1}$ (Auffan et al., 2006; Karlsson et al., 2008) although they induce oxidative stress in mice macrophages (Stroh et al., 2004).

In the present work we have investigated influence of $\mathrm{Fe}_{2} \mathrm{O}_{3} \mathrm{NP}$ and $\mathrm{Fe}_{2} \mathrm{O}_{3}$ cr. on the plant growth and development. We have evaluated phyto-, cyto- and genetoxicity of $\mathrm{Fe}_{2} \mathrm{O}_{3} \mathrm{NP}$ and $\mathrm{Fe}_{2} \mathrm{O}_{3}$ cr. on wheat ( $T$. aestivum) seeds. In addition, we have studied influence of these compounds on growth and development of tomato (Lycopersicon esculentum) plants cultivated in vitro.

\section{Materials and methods}

Seeds of wheat were treated during 24 hours at 25 ${ }^{\circ} \mathrm{C}$ with suspensions of $\mathrm{Fe}_{2} \mathrm{O}_{3}$ nanoparticles $\left(\mathrm{Fe}_{2} \mathrm{O}_{3}\right.$ $\mathrm{NP},<50 \mathrm{~nm}$, Sigma-Aldrich, USA) and $\mathrm{Fe}_{2} \mathrm{O}_{3}$ crystalline preparations $\left(\mathrm{Fe}_{2} \mathrm{O}_{3}\right.$ cr., fraction 5-10 $\mu \mathrm{m})$. Both $\mathrm{Fe}_{2} \mathrm{O}_{3} \mathrm{NP}$ and $\mathrm{Fe}_{2} \mathrm{O}_{3}$ cr. were applied in concentrations of 20,40 and $80 \mathrm{mg} \mathrm{L}^{-1}$. Blank plants were treated with distilled water.

Germination of seeds were performed in Petri dishes (20 seeds per dish) in darkness at $30{ }^{\circ} \mathrm{C}$. In vitro cultivation of $L$. esculentum plants was performed using a standard method (Butenko, 1999).

Vegetation parameters of wheat plants were evaluated measuring the germination energy and root 
growth rate. Germination energy was determined on the 4-th day as $\boldsymbol{B}=\boldsymbol{a} \boldsymbol{b}^{-1} 100 \%$, where $\boldsymbol{a}$ is a number of germinated seeds and and $\boldsymbol{b}$ is a total number of seeds.

Genetoxicity of $\mathrm{Fe}_{2} \mathrm{O}_{3} \mathrm{NP}$ and $\mathrm{Fe}_{2} \mathrm{O}_{3}$ cr. was evaluated using anaphase method of analysis of chromosomal aberrations, which were revealed in the root meristem of germinated seeds. The following aberrations were considered calculating their percentage per total number of aberrations: single chromosomal/chromatid fragments, multiple fragments, chromosome/chromatid bridges, multiple aberrations, chromosome lagging. Fixation, staining and making preparation for the light microscopy were described previously (Ham, Cormac, 1982).

Cytotoxicity was evaluated in wheat root meristem measuring mitotic index by a standard method (Grif, Machs, 1996).

In addition, presence of pinpoint aggregations of iron compounds was tested histochemically using Perls's method (Korzhevsky, Gilyarov, 2010).

Testing of statistically significant difference between the studied parameters of treated and blank (untreated) plants (done by ANOVA test) and evaluating of mean \pm SD at $p<0.05$ were performed using Microsoft Excel 2007.

\section{Results}

Data obtained on the evaluation of phytotoxicity of $\mathrm{Fe}_{2} \mathrm{O}_{3} \mathrm{NP}$ and $\mathrm{Fe}_{2} \mathrm{O}_{3}$ cr. for wheat (T. aestivum) seeds have shown clear pronounced patterns of action of these compounds. They both stimulated root growth, but in different degree. Thus, the maximum distinction in root lengths between treated with $\mathrm{Fe}_{2} \mathrm{O}_{3} \mathrm{NP}$ plants and blank plants $(70 \pm$ 6 and $47 \pm 4 \mathrm{~mm}$ respectively) was observed at 6-th day of cultivation in the experiments with $20 \mathrm{mg} \mathrm{L}^{-1}$ $\mathrm{Fe}_{2} \mathrm{O}_{3}$ NP. At that time, root lengths of plants treated with 40 and $80 \mathrm{mg} \mathrm{L}^{-1}$ were 50.5 and $66.3 \mathrm{~mm}$ (against the same blank values: $47 \mathrm{mg} \mathrm{L}^{-1}$ ). $\mathrm{Fe}_{2} \mathrm{O}_{3}$ cr. also caused elevated root growth at the 6-th day of cultivation, but the maximum effect was observed in the experiments with $80 \mathrm{mg} \mathrm{L}^{-1}$. At the 3-rd day of cultivation the maximum stimulating effect of $\mathrm{Fe}_{2} \mathrm{O}_{3}$ $\mathrm{NP}(45 \pm 4 \mathrm{~mm})$ was observed at $20 \mathrm{mg} \mathrm{L}^{-1}$ whereas in the experiments with $\mathrm{Fe}_{2} \mathrm{O}_{3}$ cr. it was observed to be $42 \pm 3 \mathrm{~mm}$ at $80 \mathrm{mg} \mathrm{L}^{-1}$ (blank values were 32 $\mathrm{mm})$.

Significant decrease in the germination rate of wheat seeds was observed after exposure of seeds to $40 \mathrm{mg} \mathrm{L}^{-1} \mathrm{Fe}_{2} \mathrm{O}_{3}$ cr. Stimulating effects on germination were observed only at $20 \mathrm{mg} \mathrm{L}^{-1} \mathrm{Fe}_{2} \mathrm{O}_{3}$ cr. Germination energy of $\mathrm{Fe}_{2} \mathrm{O}_{3} \mathrm{NP}-$ and $\mathrm{Fe}_{2} \mathrm{O}_{3}$ cr.treated seeds at all concentrations was not changed comparing to blank seeds.

In addition, we have obtained histological data demonstrating that $\mathrm{Fe}_{2} \mathrm{O}_{3} \mathrm{NP}$ may possibly penetrate wheat root meristem cells (fig. $1 \mathrm{a}$ and $1 \mathrm{~b}$ ) as far as iron was revealed in them. However, we do not exclude solving (chemical transformation) of iron in soil with the subsequent penetration of its water soluble form in cells and with the further sedimentation.

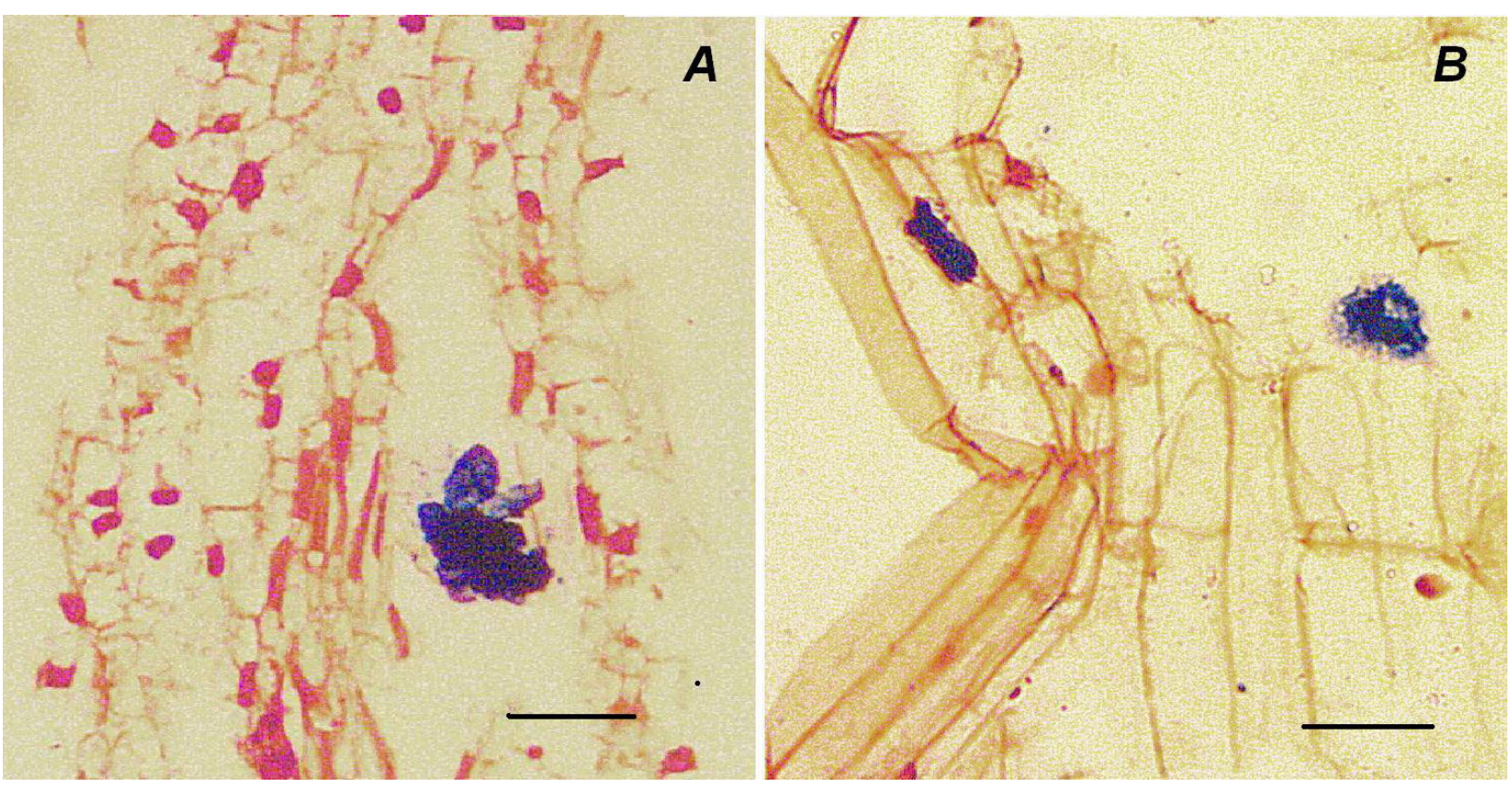

Fig. 1. Fe-clusters in histological section of wheat tissues (staining by Pearls) germinated from $\mathrm{Fe}_{2} \mathrm{O}_{3} \mathrm{NP}$-treated seeds; (a) - root parenhyma, (b) - leaf mezophyll. Bars $100 \mathrm{~mm}$. 
Results of the analysis of $\mathrm{Fe}_{2} \mathrm{O}_{3} \mathrm{NP}$ and its maximum increase was achieved at $20 \mathrm{mg} \mathrm{L}^{-1}$. $\mathrm{Fe}_{2} \mathrm{O}_{3}$ cr. cytotoxicity are shown in Table 1. All $\mathrm{Fe}_{2} \mathrm{O}_{3}$ cr. applied in the same concentrations also led the studied $\mathrm{Fe}_{2} \mathrm{O}_{3} \mathrm{NP}$ concentrations induced a to the MI increase, but it was weakly pronounced significant increase (compared to blank plants) and demonstrated tendency to significance only at of mitotic index (MI) in wheat root meristem and

concentration of $40 \mathrm{mg} \mathrm{L}^{-1}$.

Table 1

Mitotic index in wheat (Triticum aestivum) root meristem influenced by metall oxide nanoparticles and crystalline metal oxides of different concentrations

\begin{tabular}{|c|c|c|}
\hline № & Tested iron oxides of different concentrations, $\mathrm{mg} \mathrm{L}^{-1}$ & Mitotic index, mean $\pm \mathrm{SD}, \mathrm{p}<0,05$ \\
\hline 1. & Blank (distilled water) & $4.8 \pm 0.67$ \\
\hline 2. & $\mathrm{Fe}_{2} \mathrm{O}_{3} \mathrm{NP}, 20$ & $8.5 \pm 0.8^{* *}$ \\
\hline 3. & $\mathrm{Fe}_{2} \mathrm{O}_{3} \mathrm{NP}, 40$ & $7.04 \pm 0.8^{* *}$ \\
\hline 4. & $\mathrm{Fe}_{2} \mathrm{O}_{3} \mathrm{NP}, 80$ & $6.4 \pm 0.92^{*}$ \\
\hline 5. & $\mathrm{Fe}_{2} \mathrm{O}_{3}$ cr., 20 & $5.07 \pm 0.69$ \\
\hline 6. & $\mathrm{Fe}_{2} \mathrm{O}_{3}$ cr., 40 & $6.4 \pm 0.92^{*}$ \\
\hline 7. & $\mathrm{Fe}_{2} \mathrm{O}_{3}$ cr., 80 & $4.9 \pm 0.68$ \\
\hline
\end{tabular}

** - statistically significant difference in mitotic index at $\mathrm{p}<0.05$ compared to blank plants; ${ }^{*}$ - tendency to significancy of MI compared to blank plants.

Thus, the obtained data demonstrate an effect of stimulating cell divisions and tissue growth at the most of the $\mathrm{Fe}_{2} \mathrm{O}_{3} \mathrm{NP}$ and $\mathrm{Fe}_{2} \mathrm{O}_{3}$ cr. concentrations applied.

Results of the study of the mutagenic activity of $\mathrm{Fe}_{2} \mathrm{O}_{3} \mathrm{NP}$ and $\mathrm{Fe}_{2} \mathrm{O}_{3}$ cr. evaluated by the percentage of anaphases with chromosomal aberrations in wheat root meristem cells are shown in Table 2. The obtained data demonstrate that $\mathrm{Fe}_{2} \mathrm{O}_{3}$ NP ability to

induce aberration level increases with increasing its concentration. At 40 and $80 \mathrm{mg} \mathrm{L}^{-1} \mathrm{Fe}_{2} \mathrm{O}_{3} \mathrm{NP}$ this ability is significantly higher compared to blank experiments. The highest percentage of chromosomal aberrations was revealed at $80 \mathrm{Fe}_{2} \mathrm{O}_{3}$ $\mathrm{NP} \mathrm{mg} \mathrm{L}^{-1}$. In general, all the studied concentrations of $\mathrm{Fe}_{2} \mathrm{O}_{3} \mathrm{NP}$ induce the elevated rate of chromosomal aberrations compared to blank experiments.

Table 2 Level of chromosomal aberrations in wheat (Triticum aestivum) root meristem influenced by metall oxide nanoparticles and crystalline metal oxides of different concentrations

\begin{tabular}{|c|c|c|}
\hline № & $\begin{array}{c}\text { Tested iron oxides of different concentrations, } \\
\mathrm{mg} \mathrm{L}^{-1} .\end{array}$ & $\begin{array}{c}\text { Level of anaphases with chromosomal } \\
\text { aberrations, } \%, \text { mean } \pm \mathrm{SD}, \mathrm{p}<0.05\end{array}$ \\
\hline 1. & Blank (distilled water) & $2.42 \pm 0.37$ \\
\hline 2. & $\mathrm{Fe}_{2} \mathrm{O}_{3} \mathrm{NP}, 20$ & $12.2 \pm 1.07^{* *}$ \\
\hline 3. & $\mathrm{Fe}_{2} \mathrm{O}_{3} \mathrm{NP}, 40$ & $11.1 \pm 0.9^{* *}$ \\
\hline 4. & $\mathrm{Fe}_{2} \mathrm{O}_{3} \mathrm{NP}, 80$ & $15 \pm 1.12^{* *}$ \\
\hline 5. & $\mathrm{Fe}_{2} \mathrm{O}_{3}$ cr., 20 & $4.8 \pm 0.67^{*}$ \\
\hline 6. & $\mathrm{Fe}_{2} \mathrm{O}_{3}$ cr., 40 & $4.25 \pm 0.63^{*}$ \\
\hline 7. & $\mathrm{Fe}_{2} \mathrm{O}_{3}$ cr., 80 & $5 \pm 0.68^{*}$ \\
\hline
\end{tabular}

** - statistically significant difference in chromosome aberration level at $\mathrm{p}<0.05$ compared to blank plants; $*-$ tendency to significance of anaphase values compared to blank plants.

There was only the tendency to significance revealed in experiments with $\mathrm{Fe}_{2} \mathrm{O}_{3}$ cr. that suggests to the low (insufficient) difference between treated and untreated (blank) plants. The highest level of chromosome aberrations was observed at 80 $\mathrm{mg} \mathrm{L}^{-1} \mathrm{Fe}_{2} \mathrm{O}_{3}$ cr. A clear dependency between the chromosome aberration level and the concentrations applied was not found.

Analysis of chromosome aberration spectrum has shown that the extra chromosomal fragments, chromatide bridges and chromosome lags were observed most frequently.

Studies on $\mathrm{Fe}_{2} \mathrm{O}_{3} \mathrm{NP}$ and $\mathrm{Fe}_{2} \mathrm{O}_{3}$ cr. action influencing growth and development of tomato plants cultivated in vitro included evaluations of germination energy measured at 14-th day, changes in stem length at 14-th, 21-st and 28-th days of cultivation, visual determination of the number of true leaves and determination of root lengths. 
There were no changes observed in germination energy in the experiments with $\mathrm{Fe}_{2} \mathrm{O}_{3} \mathrm{NP}$ and $\mathrm{Fe}_{2} \mathrm{O}_{3}$ cr. Increase in germination energy was found to be up to $80 \%$ after application of $10 \mathrm{mg} \mathrm{L}^{-1} \mathrm{Fe}_{2} \mathrm{O}_{3}$ cr. Both $\mathrm{Fe}_{2} \mathrm{O}_{3} \mathrm{NP}$ and $\mathrm{Fe}_{2} \mathrm{O}_{3}$ cr. in concentrations 60,100 and $150 \mathrm{mg} \mathrm{L}^{-1}$ induced the decrease of germination energy, which was the most significant at $150 \mathrm{mg} \mathrm{L}^{-1} \mathrm{Fe}_{2} \mathrm{O}_{3} \mathrm{NP}$ (Table 3).

Table 3

Germination energy of tomato (Lycopersicon esculentum) seeds measured at 14-th day of cultivation influenced by metall oxide nanoparticles and crystalline metal oxides of different concentrations

\begin{tabular}{|c|c|}
\hline $\begin{array}{c}\text { Metal oxide type (nano- or crystalline) at } \\
\text { concentration, } \mathrm{mg} \mathrm{L}^{-1}\end{array}$ & Germination energy of seeds, $\%$ \\
\hline $\mathrm{Fe}_{2} 0_{3} \mathrm{NP}, 10$ & $75 \pm 6.1$ \\
\hline $\mathrm{Fe}_{2} 0_{3} \mathrm{cr}, 10$ & $74.8 \pm 6.2$ \\
\hline $\mathrm{Fe}_{2} 0_{3} \mathrm{NP}, 40$ & $81.0 \pm 6.8^{*}$ \\
\hline $\mathrm{Fe}_{2} 0_{3} \mathrm{cr}, 40$ & $75.2 \pm 6.0$ \\
\hline $\mathrm{Fe}_{2} 0_{3} \mathrm{NP}, 60$ & $73.3 \pm 5.9$ \\
\hline $\mathrm{Fe}_{2} 0_{3} \mathrm{cr}, 60$ & $68.8 \pm 4.8$ \\
\hline $\mathrm{Fe}_{2} 0_{3} \mathrm{NP}, 100$ & $65.0 \pm 4.7$ \\
\hline $\mathrm{Fe}_{2} 0_{3}$ cr., 100 & $65.4 \pm 5.0$ \\
\hline $\mathrm{Fe}_{2} 0_{3} \mathrm{NP}, 150$ & $59.1 \pm 4.6^{*}$ \\
\hline $\mathrm{Fe}_{2} 0_{3}$ cr., 150 & $65.5 \pm 5.6$ \\
\hline Blank (distilled water) & $74.9 \pm 6.0$ \\
\hline
\end{tabular}

* - statistically significant difference in percentage of anaphases with chromosomal aberrations at $\mathrm{p}<0.05$ compared to blank plants.

Data obtained on changes in tomato plant steam length at 14-th, 21-st and 28-th days of cultivation are shown in Table 4. The most pronounced inhibition of steam growth was observed at 28-th day in the experiments with $150 \mathrm{mg} \mathrm{L}^{-1} \mathrm{Fe}_{2} \mathrm{O}_{3}$ NP. Stimulation of steam growth was observed at 14-th, 21-st and 28-th days with $40 \mathrm{mg} \mathrm{L}^{-1}$ concentrations of $\mathrm{Fe}_{2} \mathrm{O}_{3}$ $\mathrm{NP}$ and $\mathrm{Fe}_{2} \mathrm{O}_{3}$ cr.

Table 4

Lycopersicon esculentum steam lenght at 14, 21 and 28 days of cultivation after passage influenced by metall oxide nanoparticles and crystalline metal oxides of different concentrations

\begin{tabular}{|c|c|c|c|}
\hline $\begin{array}{l}\text { Concentration and metal oxide } \\
\text { type (nano- or crystalline) }\end{array}$ & $\begin{array}{c}\text { Steam length at14-th day } \\
\text { after passage, } \\
\text { mean } \pm \text { SD }\end{array}$ & $\begin{array}{l}\text { Steam length at } 21 \text {-st } \\
\text { day after passage, } \\
\text { mean } \pm \mathrm{SD}\end{array}$ & $\begin{array}{c}\text { Steam length at } 28 \text {-th day } \\
\text { after passage, } \\
\text { mean } \pm \mathrm{SD}\end{array}$ \\
\hline $\mathrm{Fe}_{2} 0_{3} \mathrm{NP}, 10 \mathrm{mg} \mathrm{L}^{-1}$ & $8.3 \pm$ & $10.5 \pm$ & $15.0 \pm *$ \\
\hline $\mathrm{Fe}_{2} 0_{3}$ cr., $10 \mathrm{mg} \mathrm{L}^{-1}$ & $8.2 \pm$ & $10.0 \pm$ & $15.2 \pm *$ \\
\hline $\mathrm{Fe}_{2} \mathrm{O}_{3} \mathrm{NP}, 40 \mathrm{mg} \mathrm{L}^{-1}$ & $10 \pm *$ & $12.1 \pm *$ & $17.8 \pm *$ \\
\hline $\mathrm{Fe}_{2} 0_{3}$ cr., $40 \mathrm{mg} \mathrm{L}^{-1}$ & $9 \pm *$ & $12.0 \pm *$ & $17.5 \pm *$ \\
\hline $\mathrm{Fe}_{2} 0_{3} \mathrm{NP}, 60 \mathrm{mg} \mathrm{L}^{-1}$ & $8.3 \pm$ & $10.1 \pm$ & $16.1 \pm$ \\
\hline $\mathrm{Fe}_{2} 0_{3}$ cr., $60 \mathrm{mg} \mathrm{L}^{-1}$ & $8.2 \pm$ & $9.8 \pm$ & $16.3 \pm$ \\
\hline $\mathrm{Fe}_{2} 0_{3} \mathrm{NP}, 100 \mathrm{mg} \mathrm{L}^{-1}$ & $7.6 \pm$ & $9.0 \pm *$ & $12.2 \pm *$ \\
\hline $\mathrm{Fe}_{2} 0_{3}$ cr., $100 \mathrm{mg} \mathrm{L}^{-1}$ & $8.0 \pm$ & $9.5 \pm$ & $12.5 \pm *$ \\
\hline $\mathrm{Fe}_{2} 0_{3} \mathrm{NP}, 150 \mathrm{mg} \mathrm{L}^{-1}$ & $7.1 \pm *$ & $8.6 \pm *$ & $11.0 \pm *$ \\
\hline $\mathrm{Fe}_{2} 0_{3}$ cr., $150 \mathrm{mg} \mathrm{L}^{-1}$ & $7.3 \pm *$ & $8.7 \pm *$ & $11.0 \pm *$ \\
\hline Blank (distilled water) & $8.0 \pm$ & $10.0 \pm$ & $16.5 \pm$ \\
\hline
\end{tabular}

* - statistically significant difference of steam lenght at $\mathrm{p}<0.05$ compared to blank plants.

Root lengths of tomato seeds were measured at 28-th day of cultivation in the presence of $\mathrm{Fe}_{2} 0_{3} \mathrm{NP}$ and $\mathrm{Fe}_{2} \mathrm{O}_{3} \mathrm{cr}$. The obtained data are shown in Table 5.

The plants cultivated in vitro in the presence of the highest concentrations of $\mathrm{Fe}_{2} \mathrm{O}_{3} \mathrm{NP}$ (100 and
$150 \mathrm{mg} \mathrm{L}^{-1}$ ) have the minimal root lengths. There were no significant changes of root lengths of plants treated with other concentrations compared to blank plants. 
Root lengths of Lycopersicon esculentum seeds at 28-th day of cultivation in the presence of $\mathrm{Fe}_{2} \mathrm{O}_{3} \mathrm{NP}$ and $\mathrm{Fe}_{2} \mathrm{O}_{3} \mathrm{cr}$.

\begin{tabular}{|c|c|}
\hline $\begin{array}{c}\text { Concentration and metal oxide type (nano- or } \\
\text { crystalline) at concentration, } \mathrm{mg} \mathrm{L}^{-1}\end{array}$ & $\begin{array}{c}\text { Root length, } \mathrm{mm}, \\
\text { mean } \pm \mathrm{SD}\end{array}$ \\
\hline $\mathrm{Fe}_{2} 0_{3} \mathrm{NP}, 10$ & 18.2 \\
\hline $\mathrm{Fe}_{2} 0_{3}$ cr., 10 & 17.5 \\
\hline $\mathrm{Fe}_{2} 0_{3} \mathrm{NP}, 40$ & $17.6^{*}$ \\
\hline $\mathrm{Fe}_{2} 0_{3}$ cr., 40 & 16 \\
\hline $\mathrm{Fe}_{2} 0_{3} \mathrm{NP}, 60$ & 17 \\
\hline $\mathrm{Fe}_{2} 0_{3}$ cr., 60 & $16^{*}$ \\
\hline $\mathrm{Fe}_{2} 0_{3} \mathrm{NP}, 100$ & $12^{*}$ \\
\hline $\mathrm{Fe}_{2} 0_{3}$ cr., $100 \mathrm{mg}$ & $12.5^{*}$ \\
\hline $\mathrm{Fe}_{2} 0_{3} \mathrm{NP}, 150 \mathrm{mg}$ & $10^{*}$ \\
\hline $\mathrm{Fe}_{2} 0_{2}$ cr., $150 \mathrm{mg}$ & $9.6^{*}$ \\
\hline Blank (distilled water) & 19 \\
\hline
\end{tabular}

$*$ - statistically significant difference in root lenght at $\mathrm{p}<0.05$ compared to blank plants.

\section{Discussion}

Previous researches carried out mainly with animals have shown genetoxicity of titanium and zinc oxide NP whereas there are no data on iron oxide NP genotoxicity for plant cells as well as for animal cells. The direct mechanisms of metal oxide genotoxicity (for $\mathrm{Ti}, \mathrm{Zn}, \mathrm{Ag}, \mathrm{Al}$ ) are based on DNA strand breaks revealed in most cases by molecular methods (reviewed by Xie etal., 2011; Klien, GodnićCvar, 2012). Evidently these mechanisms allow to suppose generation of chromosome aberrations, which, however, are studied by researchers quite rarely. For example, aluminum oxide NP are among a small number of exclusions (Balasubramanyam et al., 2009). Nevertheless, as far as the chromosome aberrations often are the "end point" ofDNA damage, they should be studied necessarily. In this context, the main finding of our work is that the genetoxicity of iron oxide nanoparticles was revealed in plants for the first time using the anaphase method of analysis of chromosomal aberrations. However, these studies require to be continued in the future to obtain a detailed information on size effects of $\mathrm{Fe}_{2} \mathrm{O}_{3} \mathrm{NP}$.

Data obtained in our research on vegetation parameters of plants confirm general previous results from a wide range of various studies (Xie et al., 2011; Klien, Godnić-Cvar, 2012; Vishnu et al., 2018, 2019;) which demonstrate a complicated dose-dependent NP-induced response of plant cells. Our results obtained from in vitro studies may be of special interest regarding use the tissue culture method in NP-toxicology researches. They suggest that plant tissue culture may be a convenient and sensitive method to test metal NP toxicity, which is known to have an advantage in high reproducibility.

Author hope that their results will stimulate further researches on toxicity of the metal oxide nanoparticles.

\section{Acknowledgements}

Authors are grateful to the Ministry of Education and Science of Russian Federation for the financial support in the framework of the grant 6.6222.2017/8.9. "Development of strategy, methods and technologies of conservation and efficient use of biological diversity in natural and urbanized areas of the steppe zone of the European part of Russia" and performed with the equipment of Multiaccess Center "Biotechnology, Biomedicine and Environmental Monitoring"..

\section{REFERENCES}

Alidoust D., Isoda A. 2014. Phytotoxicity assessment of $\gamma-\mathrm{Fe}_{2} \mathrm{O}_{3}$ nanoparticles on root elongation and growth of rice plant. Environmental Earth Sciences 71(12): 5173-5182.

Auffan M., Decome L., Rose J., Orsiere T., Méo M., Briois V., Chanéac C., Olivi L., Bergé-Lefranc J-L., Botta A., Wiesner M., Bottero J-Y. 2006. In vitro interactions between DMSA-coated maghemite nanoparticles and human fibroblasts: a physicochemical and cyto-genotoxical study. Environmental Sciences and Technology 40(14): 4367-4373. 
Balasubramanyam A., Sailaja N., Mahboob M., Rahman M., Misra S, Hussain S., Grover P. 2009. Evaluation of genotoxic effects of oral exposure to aluminum oxide nanomaterials in rat bone marrow. Mutation Research 676: 41-47.

Barrena E., Casals E., Colon J., Fon Xt., Sanchez A., Puntes V. 2009. Evaluation of the ecotoxicity of model nanoparticles. Chemosphere.75(7): 850-857.

Butenko R. G. 1999. Biology of higher plant cells in vitro and biotechnology based on them. FBK-PRESS, Moscow, 158 pp. [In Russian]. (Бутенко P. Г. Биология клеток высших растений in vitro и биотехнологии на их основе. М.: ФБК-ПРЕСС, 1999. 158 с.).

Churilov G. I., Nazarova A. A., Ampleeva L. E., Polishchuk S. D., Cherkasov O. V. 2010. The biological effect of nanoscale metals on various groups of plants. Ryazan, 148 pp. [In Russian]. (Чурилов Г. И., Назарова А. А., Амплеева Л. Е., Полищук С. Д. Черкасов О. В. Биологическое действие наноразмерных металлов на различные группы растений. Рязань, 2010. 148 с.).

Deryabina T. D. 2015. Adaptive reactions and tolerance limits of Triticum aestivum and Allium cepa to copper and iron nanoparticles. Diss. of the PhD. Orenburg, 123 pp. [In Russian]. (Дерябина Т. Д. Адаптивные реакции и пределы толерантности Triticum aestivum и Allium сера к наночастицам меди и железа: дис. ... канд. биол. наук. Оренбург, 2015. 123 с.).

Godimchuk A. Yu., Ikhalainen E. S. 2013. Influence of highly dispersed particles of different nature on the early stages of ontogenesis of rapeseed plants (Brassica napus). Naukovedenie 5: 2-17 [In Russian]. (Годымчук A. Ю., Ихалайнен $\boldsymbol{E}$. $\boldsymbol{C}$. Влияние высокодисперсных частиц различной природы на ранние стадии онтогенеза растений рапса (Brassica napus) // Науковедение, 2013. № 5. С. 2-17.).

GOST R 52325-2005. 2005. Seeds of agricultural plants. Varietal and sowing characteristics. General specifications. Last updated 23.06.2009. Last accessed 2.12.2018: Status: currently applicable [In Russian]. (ГOCT P 523252005. Семена сельскохозяйственных растений. Сортовые и посевные качества. Общие технические условия. Дата последнего изменения: 23.06.2009). URL: http://uralniishoz.ru/uploadedFiles/files/gost_r_52325-2005.pdf

GOST R 50260-92. 1993. Seed dressing of onions, carots and tomatoes. Sowing characteristics. Specifications Last updated 01.12.2003. Last accessed 2.12.2018: Status: currently applicable [In Russian]. (ГOCT P 50260-92. Семена лука, моркови и томата дражированные. Посевные качества. Технические условия. Дата введения: 01.07.1993). URL: https://docs.cntd.ru/document/gost-r-50260-92

Grif V. G., Machs E. M. 1994. Rhythms of mitotic activity and cell cycles in plant meristems. Cytology 36(11): 1069-1080.

Ham A., Cormac D. 1982. Histology. Vol. 1. Mir, Moscow, 136 pp. [In Russian]. (Хэм А. Кормак Д. Гистология. B 5 тT. T. 1.136 c.).

He S., Feng Y., Ren H., Zhang Y., Gu N., Lin X. 2011. The impact of iron oxide magnetic nanoparticles on the soil bacterial community. Journal of Soils and Sediments 11(8): 1408-1417.

Karlsson R.-M., Hefner K., Sibley D., Holmes A. 2008. Comparison of dopamine D1 and D5 receptor knockout mice for cocaine locomotor sensitization. Psychopharmacology (Berl.) 200(1): 117-127.

Kim D., Gopal J., Sivanesan I. 2017. Nanomaterials in plant tissue culture: the disclosed and undisclosed. RSC Advance (IF 2.936). DOI: 10.1039/C7RA07025J

Klien K., Godnić-Cvar J. 2012. Genotoxicity of metal nanoparticles: Focus on in vivo studies. Archives of Industrial Hygiene and Toxicology 63: 133-145

Kolesnikov S. I., Timoshenko A. N., Kazeev K. Sh., Akimenko Yu. V. 2016. Influence of pollution of nickel and iron oxides with nanoparticles on the biological properties of the chernozem. Izvestiya visshih uchebnih zavedeniy. North Caucasus region. Series: Natural Sciences 1(189): 71-75 [In Russian]. (Колесников С. И., Тимошенко А. Н., Казеев К. Ш., Акименко Ю. В. Влияние загрязнения наночастицами оксидов никеля и железа на биологические свойства чернозема обыкновенного североприазовского // Известия высших учебных заведений. Северо-Кавказский регион. Серия: Естественные науки, 2016. № 1(189). С. 71-75).

Korzhevsky D. E., Gilyarov A. V. 2010. Basics of histological technique. SpecLit, St. Petersburg, 95 pp. [In Russian]. (Коржевский Д. Э., Гиляров А. В. Основы гистологической техники. СПб.: СпецЛит, 2010.95 с.).

Lei Z., Fashui H., Shipeng L., Liu C. 2005. Effect of nano- $\mathrm{TiO}_{2}$ onstrength of naturally aged seeds and growth of spinach. Biological Trace Element Research 104: 83-91.

Mahmoudi M., Hofmann H., Rothen-Rutishauser B., Petri-Fink A. 2012. Assessing the in vitro and in vivo toxicity of superparamagnetic iron oxide nanoparticles. Chem. Rev. 112(4): 2323-2338.

Nazarova A. A., Kutskir M. V. 2012. Features of the action of nanoscale particles of copper on the physiological processes in the plant organism. In: Modern Chemical Physics: Materials of the conference. Tuapse, 93-94 pp. [In Russian]. (Назарова A. A., Куцкир М. В. Особенности действия наноразмерных частиц меди на физиологические процессы в растительном организме // Современная химическая физика: Материалы конф. Туапсе, 2012. C. 93-94).

Siddiqui M., Al-Whaibi M. 2014. Role of nano- $\mathrm{SiO}_{2}$ in germination of tomato (Lycopersicum esculentum seeds Mill.). Saudi J. Biol. Sci. 21(1): 13-17. DOI: 10.1016/j.sjbs.2013.04.005 
Vinogradov D. V. 2010. The influence of nanocrystalline iron metal on the productivity of spring rapeseed. In: Innovative technologies and technical means of cultivation of forage crops in dry farming areas based on adaptive and promising farming systems. Materials of the conf. Volgograd, 43-45 pp. [In Russian] (Виноградов Д. В. Влияние нанокристаллического металла железа на продуктивность ярового рапса // Инновационные технологии и технические средства возделывания кормовых культур в зонах сухого земледелия на основе адаптивных и перспективных систем земледелия: материалы конф. Волгоград, 2010. С. 43-45).

Vishnu R., Minkina T., Fedorenko G., Sushkova S., Mandzhieva S., Lysenko V., Duplii N., Fedorenko G., Dvadnenko K., Ghazaryan K. 2018. Toxicity of copper oxide nanoparticles on spring barley (Hordeum sativum distichum). Science of The Total Environment 645: 1103-1113.

Xie H., Mason M. M., Wise J. P. Sr. 2011. Genotoxicity of metal nanoparticles. Reviews on Environmental Health 26: $251-68$. 